\title{
Türkiye'de Altyapıdan Futbolcu Yetişememesinin Nedenleri ve Çözüm Önerileri Üzerine Nitel Bir Araştırma*
}

\author{
A Qualitative Research on Reasons Why Turkish Football Clubs Are Unable to \\ Train Youth Team Players Well and Possible Solutions
}

\author{
Sefa ÇEVIK ${ }^{1+}$ \\ Zeynep ONAĞ $\breve{C}^{2}$
}

ORİJINAL ARAŞTIRMA/

ORIGINAL RESEARCH

\begin{abstract}
${ }^{1}$ Manisa Celal Bayar Üniversitesi, Spor Bilimleri Fakültesi, Manisa https://orcid.org/0000-0001-5394-1590 ${ }^{2}$ Manisa Celal Bayar Üniversitesi, Spor Bilimleri Fakültesi, Manisa https://orcid.org/0000-0002-4034-6773
\end{abstract}

$\ddot{\mathbf{O z}}$

$\mathrm{Bu}$ araştırmanın amacı profesyonel futbol kulüplerindeki alt yapı sorununu değerlendirerek, Türkiye'de alt yapıdan futbolcu yetiştirilememesinin nedenlerini, kulüplerin alt yapıdan sporcu yetiştirebilmek için neler yaptıklarını ve altyapıdan futbolcu yetiştirilebilmesi için neler yapılabilir noktasını değerlendirmek ve öneriler sunabilmektir. Araştırmada, nitel araştırma yöntemlerinden durum çalışması yöntemi kullanılmıştır. Örneklem seçiminde ise, amaçlı örneklem yöntemlerinden kolay ulaşılabilir durum örneklemesine başvurulmuştur. Veri toplama yöntemi olarak, görüşme yaklaşımı kullanılmış ve görüşmeler yarı yapılandırılmış görüşme formu kullanılarak gerçekleştirilmiştir. Araştırmanın çalışma grubu, yaşları 35-63 arası değişen, farklı düzeylerdeki futbol liglerinde ortalama 5 yıl teknik sorumlu veya idariyöneticilik deneyimine sahip, araştırmaya gönüllü olarak katılan 18 kişiden oluşmaktadır. Araştırmada, veri analizleri betimsel analiz yöntemi ile değerlendirilmiş ve bulgular, "Türkiye'de altyapıdan futbolcu yetişmemesinin nedenleri", "kulüp bazında alt yapıdan futbolcu yetişmesi ile ilgili yapılan çalışmalar " ve "Türkiye'de altyapıdan futbolcu yetişmesi için yapılabilecek çalışmalar" olmak üzere 3 ana tema altında toplanmıştır.

Anahtar Kelimeler: Futbol, Altyap1, Futbolcu yetiştirmek.

\section{Yayın Bilgisi}

Gönderi Tarihi: 23.10.2019

Kabul Tarihi: 25.12.2019

Online Yayın Tarihi: 31.12.2019

DOI: $10.33459 /$ cbubesbd.637214

\begin{abstract}
The aim of this research is to suggest possible solutions by evaluating the problem of youth teams in Turkish professional football clubs and the reasons why new young players cannot be trained well, by assessing what clubs currently do and what might be done in order to bring up players from youth teams. The method of the case study, one of qualitative research methods is used in this research. Convenience sampling, which is one of the methods of purposeful sampling was chosen as the method of sampling. As for the method of data collection, interview approach was used and the interviews were carried out using a semi structured interview form. The sample group which has participated in this research consists of 18 voluntary people who are aged from 35to 63 and have an average experience of 5 years working as a coach or part of administrative body. In the research, data analysis was evaluated via the descriptive analysis method the findings were collected under three main topics, "The reasons Turkish football clubs are unable to train youth team players well", "The work currently being done in order to train youth team players on a club basis in Turkey" and "The work which can be done in order to train youth team players well in Turkey".
\end{abstract}

Keywords: Football, Youth team, Training youth team.

* Bu araştırma, 21 - 23 Mayıs 2017 tarihlerinde Bursa'da düzenlenen Uluslararası Balkan Spor Bilimleri Kongresi’nde sözel sunum olarak sunulmuştur.

†Sorumlu yazar: sefacevik90@gmail.com 


\section{GİRIŞ}

Futbolda başarının formülü, elit futbolcu yetiştirilmesinden geçtiği söylenmektedir. Buna bağlı olarak da, üst düzeydeki futbol takımlarının alt yapılarında kaliteli ve yetenekli futbolcuları ortaya çıkartması gerektiği düşünülmektedir. Dünyada büyük bir sektör olan futbol branşında kulüpler pahalı transferler yaparak futbolculara büyük paralar ödemektedirler. Bu kadar maliyetli bir durumdan kurtulabilmek için kulüplerin kendi altyapılarından futbolcu yetiştirerek yüksek maliyetlerden kurtulabilecekleri akla gelmektedir.

Ülkemizdeki en üst düzeydeki lig olan, Spor Toto Süper Lig'de yer alan 18 futbol kulübü incelendiğinde, 2017-2018 sezonunun ilk yarısında altyapılarından yetiştirdiği oyuncuların ligde oynama sayılarına göre, yalnızca 80 futbolcunun kadroda yer aldığı ve bu futbolculardan da ancak 27'sinin ilk yarıda ligde oynama şansı buldukları görülmüştür (Türkiye Futbol Federasyonu, 2017).

Bütün ligdeki takımların kadrolarında yer alan oyuncu sayısının ortalama 450 olduğu göz önünde bulundurulduğunda, kendi kulübünün altyapısından yetişen ve ilk yarıda forma giyme şansı olan oyuncuların oranının ne yazık ki yüzde 6 olduğu görülmektedir. Takımlara bakıldığında en çok alt yapıdan oyuncu ile oynayan kulüplerin Adanaspor AŞ, Bursaspor ve Trabzonspor takımlarında 5'er oyuncu ile oynadıklarını, üç büyükler olarak tabir edilen Galatasaray 2, BJK 2 ve Fenerbahçe Spor Kulübünün ise hiç altyapıdan futbolcusunu ilk yarıda değerlendirmediği görülmektedir.

Bu bağlamda, Spor Toto Süper Lig'deki takımların alt yapıdaki sporculara yer verememelerinin nedenlerinin alt yapıda yetenekli ve nitelikli futbolcuların yetişemediği sorusunu akla getirmektedir. Peki, kendi altyapılarından neden futbolculara yer vermiyorlar ya da yetiştiremiyorlar. Bu bağlamda, bu araştırmanın amacı profesyonel futbol kulüplerindeki alt yapı sorununu değerlendirerek, ülkemizde alt yapıda neden futbolcu yetiştirilmediğini, kulüplerin alt yapıdan sporcu yetiştirebilmek için neler yaptıklarını ve altyapıdan futbolcu yetiştirilebilmesi için neler yapılabilir noktasını değerlendirmek ve öneriler sunabilmektir.

\section{Altyapı Kavramı}

Takım sporlarında, 1. takıma veya profesyonel takıma yeni sporcular kazandırabilmek amacıyla uygulanan sistem altyapı sistemidir. Alt yaş gruplarında antrenmanlara çıkan ve müsabakalarda yer alan sporcular yetenek ve potansiyellerine göre 1. takımda yer alırlar. Başka bir yöntem ise sporcuların daha fazla tecrübe kazanması amacıyla diğer takımlara kiralanması ve 
satılmasıdır. ABD'de genç sporcular lise kolej vb. gibi yerlerde yetiştirilerek takımlara kazandırılmaktadır. Genel olarak futbolda ise, her bir takım kendi altyapı ve akademi tesislerinde genç futbolculara eğitim vermektedir (BBC, 2005).

Futbolda altyapı sistemi, 12 yaş ve üzerindeki genç futbolculardan oluşan yarışmacı takımların olduğu sistemdir. Bu takımların oluşabilmesi için, temel futbol eğitimi almış, doğru antrenman ve hareket metotları ile yetişmiş genç futbolculara ihtiyaç duyulmaktadır. Statüsü amatör veya profesyonel olan tüm futbol kulüplerinin öncelikli hedefinin genç futbolcu yetiştirmek ve doğru bir şekilde futbol eğitimi vermek olması hem takımlar hem de gençler için olumlu bir adım olacaktır. Bu süreç içerisinde okullar ile işbirliğine varmak ve gençlerin eğitim sürecini de değerlendirmek daha sağlıklı bir sistem oluşturacaktır (TFF.org).

\section{Futbolda Altyapı Kavramı ve Futbolcu Yetiştirme}

Günümüzde genç futbolcu yetiştirmede dünya çapında kabul gören ortak değerler bulunmaktadır. Futbolcu geliştirme ve yetiştirmedeki doğru prensipler açık bir şekilde bilinmektedir. Kulüpler tarafından bu prensiplerin uygulanması ve detaylandırılmasının başarıyı getireceği düşünülmektedir. Genç futbolcu adayları için altyapıda geçirdiği sürede aldığı eğitim ve as takıma çıkış süreci büyük önem taşımaktadır. Bu süreç hem kulüp hem futbolcu açısından iyi değerlendirdiğinde değer yaratma konusunda başarıya ulaşılabilmektedir. Dünya çapında kulüpler, ekonomik sebepler ve kulübe katkı sağlayacak futbolcular yetiştirme amacıyla altyapıya önem vermektedirler (Bayraktar, 2017).

Genç futbolcuların aldıkları futbol eğitiminin yanı sıra okuldaki başarışı da sporcu yetiştirmede önemli bir etkendir. Spor kulüpleri, liseler üniversiteleri ile işbirliği halinde olması ve genç futbolcuların ders çalışmaları için kendi bünyesinde imkânlar sağlaması gençlerin okul eğitimlerinin de devamı açısından faydalı olacağı düşünülmektedir.

Günümüzdeki çocukların spor yapamamalarına etki eden unsurlardan bir tanesinin de açık oyun alanlarının kısıtlı olması olduğu düşünülmektedir. Bu nedenden dolayı çocuklar hem iyi bir eğitim alabilmek amacı ile hem de aidiyet duygularının gelişim için spor kulüplerini tercih etmektedirler. Çocuklar yönlendiği ve yönlendirdikleri branşın eğitimini kulüpler aracıllğı ile almaktadırlar. "Okul Sporları Federasyonu'nun" kurulması okul spor kulüplerinin de kurulmasına yol açmış ve yetenek taraşı seçim ve yönlendirme önem kazanmıştır. Dünyadaki bazı ülkelere bakıldığında (Polonya, Brezilya, Hollanda, Arjantin ve Meksika) futbol eğitimi ve 
yönlendirmeyi kulüpler bazında düzenlenmiştir. Bu ülkelerin sahip olduğu nüfusa oranla futbol akademilerindeki takım sayıları daha ülkemize göre daha yüksek seviyededir (Küçük, 2009).

\section{YÖNTEM}

Araştırmanın Modeli: Araştırmada katılımcıların görüşlerine göre Türkiye'de futbolcu yetişememesinin nedenleri ve çözüm önerileri nitel araştırma tekniklerinden durum çalışması yöntemi kullanılarak saptanmaya çalışılmıştır. Nitel araştırma, görüşmelerin, gözlemlerin, eldeki doküman ve verilerin analizlerini içeren, nitel veri toplama prensiplerinin uygulandığı, olay ve algıların doğal bir şekilde gerçek ve bütün olarak ortaya çıkarılmasına yönelik nitel olarak izlenen süreç olarak tanımlanabilmektedir (Yıldırım ve Şimşek, 2006).

Katılımcılar: Araştırmanın katılımcıları, Spor-Toto Süper Lig kulüplerinin futbol akademileri ve futbol altyapılarında görev alan; Adanaspor, Akhisar Bld. Gençlik ve Spor, Bursaspor, Fenerbahçe, Gaziantepspor, Gençlerbirliği, Karabükspor, Kasımpaşa, Kayserispor, Başakşehir FK, Trabzonspor takımlarının Gençlik Geliştirme Programı teknik sorumluları, Konyaspor, Beşiktaş, Galatasaray kulüplerinin idari direktörleri ve Antalyaspor, Alanyaspor, Ç. Rizespor ve Osmanlıspor'da görev alan genç takım antrenörlerinden oluşmaktadır. Araştırmanın çalışma grubu, yaşları 35-63 arasında değişen, farklı düzeylerdeki futbol liglerinde ortalama 5 yıl teknik sorumlu veya idari-yöneticilik deneyimine sahip, araştırmaya gönüllü olarak katılan 18 kişiden oluşmaktadır. Araştırma grubunu, takımlarının alt yapılarında görev alan; "Gençlik Geliştirme Programı Teknik Sorumluları" "İdari Yöneticiler" ve alt yapıdan sorumlu “Antrenörler” oluşturmaktadır. 
Tablo 1. Katılımcılara ilişkin kişisel bilgiler

\begin{tabular}{|c|c|c|c|c|c|c|c|c|}
\hline Katılımcı & Cinsiyet & Yaş & $\begin{array}{l}\text { Eğitim } \\
\text { Durumu }\end{array}$ & $\begin{array}{l}\text { Medeni } \\
\text { Durum }\end{array}$ & $\begin{array}{l}\text { Kulüpteki } \\
\text { Görevi }\end{array}$ & $\begin{array}{l}\text { Görev } \\
\text { Süresi }\end{array}$ & $\begin{array}{l}\text { Meslek } \\
\text { Süresi }\end{array}$ & $\begin{array}{l}\text { Kulüpte } \\
\text { Çalș. Sür. }\end{array}$ \\
\hline K1 & Erkek & 51 & Lise & Evli & GGP Tek & 2 & 10 & 10 \\
\hline K2 & Erkek & 47 & Lise & Evli & GGP Tek & 2 & 11 & 2 \\
\hline K3 & Erkek & 45 & Üniversite & Evli & GGP Tek & 4 & 12 & 4 \\
\hline K4 & Erkek & 46 & Lise & Evli & GGP Tek & 4 & 7 & 7 \\
\hline K5 & Erkek & 55 & Üniversite & Evli & GGP Tek & 2 & 10 & 7 \\
\hline K6 & Erkek & 52 & Lise & Evli & GGP Tek & 15 & 20 & 20 \\
\hline K7 & Erkek & 63 & Lise & Evli & İdari-Yön. & 2 & 25 & 20 \\
\hline K8 & Erkek & 50 & Lise & Evli & Antrenör & 1 & 18 & 18 \\
\hline K9 & Erkek & 55 & Lise & Evli & Antrenör & 1 & 17 & 17 \\
\hline K10 & Erkek & 55 & Lise & Evli & GGP Tek. & 20 & 20 & 20 \\
\hline K11 & Erkek & 35 & Üniversite & Evli & İdari-Yön. & 4 & 4 & 4 \\
\hline K12 & Erkek & 42 & Lise & Evli & Antrenör & 2 & 9 & 2 \\
\hline K13 & Erkek & 57 & Lise & Evli & GGP Tek. & 2 & 25 & 2 \\
\hline K14 & Erkek & 57 & Lise & Evli & GGP Tek. & 3 & 21 & 3 \\
\hline K15 & Erkek & 46 & Lise & Evli & Antrenör & 12 & 15 & 12 \\
\hline K16 & Erkek & 43 & Üniversite & Evli & İdari- Yön. & 10 & 10 & 10 \\
\hline K17 & Erkek & 59 & Lise & Evli & GGP Tek. & 10 & 20 & 12 \\
\hline K18 & Erkek & 51 & Lise & Evli & Antrenör & 12 & 20 & 12 \\
\hline
\end{tabular}

\section{Veri Toplama Araçları}

Araştırmada veri toplama aracı olarak yarı yapılandırılmış görüşme formu kullanılmıştır. Ayrıca, görüşme yapılan katılımcılar hakkında kişisel bilgiler edinebilmek amacı ile araştırmacılar tarafından hazırlanmış "bilgi formu” kullanılmıştır.

\section{Görüşmeler}

Görüşme öncesi katılımcılardan randevu alınmış ve çalışma ile ilgili gerekli bilgilendirmeler yapılmıştır. Görüşmeler ses kayıt cihazı aracılığı ile kaydedilmiştir. Ses kayıt işlemi araştırmacı tarafından yapılmıştır. Bilgi formu ve görüşme soruları, araştırmacılar ve alanında uzman kişiler bir araya gelerek oluşturulmuştur.

\section{Geçerlik ve Güvenirlik}

Geçerlik çalışması aşağıdaki hususlar ışığında yapılmıştır.

$\checkmark$ Elde edilen bulguların tutarlı ve anlamlı olmasına önem gösterilmiştir.

$\checkmark$ Bulguların anlamlı ve bütünsel olması sağlanmıştır. 
$\checkmark$ Elde edilen verilerin önceden oluşturulmuş kavramsal çerçeve ile bütünleşme içindedir. Bu çerçeve, veri toplamada kaynak niteliği taşımış ve uygulamanın gerçekleşmesinde yardım sağlamıştır.

$\checkmark$ Elde edilen bulgular, ses kaydı olarak kaydedilmiş aynı zamanda not alınarak gözden geçirilmiştir. Bu sayede bulgular kendi içinde anlamlı bir bütün sağlamıştır. Böylece bulguların anlamlı bir bütün oluşturulması sağlanmıştır.

Araştırmada güvenirlik çalışması aşağıdaki hususlar ışı̆̆ında yapılmıştır:

$\checkmark$ Araştırmacı tarafından hem araştırmanın yöntemleri hem de aşamaları net ve ayrıntılı bir şekilde tanımlamıştır.

$\checkmark$ Sonuçlar, verilerle net bir şekilde ilişkilendirilmiştir.

$\checkmark$ Araştırmacı tarafindan izlenen yöntem ve süreç ayrıntılarıyla birlikte tanımlanmıştır.

$\checkmark$ İşlenmemiş veriler başka kişiler tarafından da incelenebilecek bir şekilde saklanmıştır.

$\checkmark$ Araştırma soruları net bir şekilde ifade edilmiştir.

$\checkmark$ Araştırmada elde edilen sonuçlar, verilerle uyum içindedir.

$\checkmark$ Veriler araştırma sorularının gerektiği şekilde ayrıntıları ile beraber amacına uygun bir şekilde toplanmıştır (Yıldırım ve Şimşek, 2006).

\section{Verilerin Analizi}

Araştırmanın verilerinin net bir şekilde anlaşılması ve çözümlenebilmesi, neden-sonuç ilişkileri irdelendikten sonra sonuçlara ulaşılması ve elde edilen bulguların yorumlanması adına nitel analiz yöntemlerinden olan "betimsel analiz" yöntemine başvurulmuştur (Yıldırım ve Şimşek, 2006). Bu analiz ile birlikte işlenmemiş veriler okurların anlayacağı ve isterlerse kullanabilecekleri bir biçim almaktadır.

Görüşme sırasında yapılan ses kayıtları bilgisayarda yazıya geçirilerek kaydedilmiştir. Kayıtlar tek bir metin halinde toplanarak kodlanmıştır. Strauss ve Corbin (1990)'in "verilerden çıkarılan kavramlara göre yapılan kodlama" biçiminden yola çıkarak araştırma verilerinin kodlanması sağlanmıştır. Bu kodlama türü sayesinde araştırmacı metini okur ve araştırmanın amacından yola çıkarak önemli hususları belirler. Elde ettiği anlamlardan kodlar çıkarabilir veya verilerden kodlar oluşturabilir. Böylece tüm verilerin işlenebilmesi için kavramsal yapı ile birlikte 
kod listesi de oluşmaktadır. Tümevarımcı analizde kodlar verilerden üretilmektedir (Yıldırım ve Şimşek, 2006).

\section{BULGULAR ve TARTIŞMA}

Görüşmeler sonucunda elde edilen veriler üç ana başlık altında sunulmuştur.

Şekil 1. Genel Tema ve Alt Boyutları

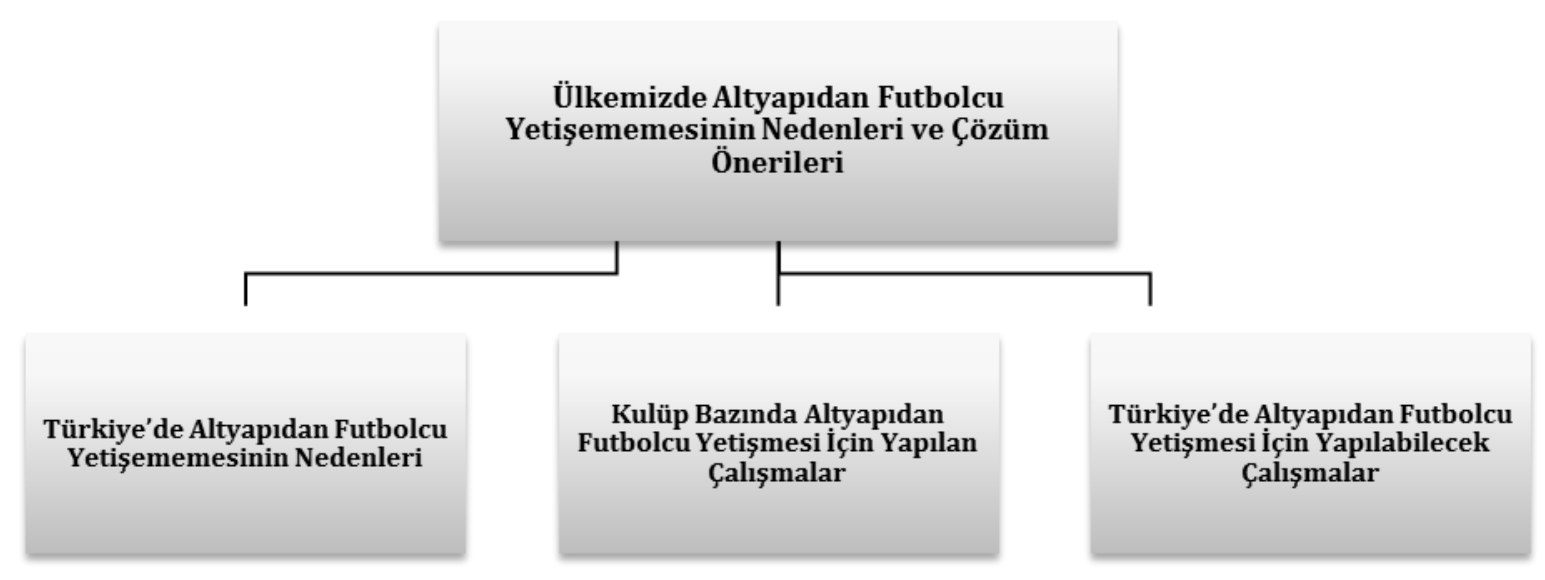

1. Ana Tema'da Türkiye'de futbolcu yetişememesi üzerine görüşler üzerinden elde edilen verilerin analizi ile yapılan kodlamalar "alt temalar" adı altında yedi başlıkta toplanmıştır.

\begin{tabular}{|c|c|c|c|}
\hline & $\begin{array}{l}\text { Görüşsme Sonucu Ortaya } \\
\text { Çıkan Kodlar }\end{array}$ & Alt Temalar & Katılımeılar \\
\hline \multirow{7}{*}{$\begin{array}{l}\text { Size göre Türkiye'de } \\
\text { altyapıdan futbolcu } \\
\text { yetişememesinin } \\
\text { nedenleri nelerdir? }\end{array}$} & Tesisleşme yetersizliği & Tesis & $\begin{array}{l}\text { K1-K2-K3-K4-K6-K11 } \\
\text { K14- K16 }\end{array}$ \\
\hline & Eğitim yetersizliği & Eğitim & K1-K3-K7-K11 \\
\hline & Denetim yetersizliği & Denetim & K1 \\
\hline & Maddi durumların kısitlılı̆̆ & Maddi durum & $\mathrm{K} 1$ \\
\hline & Genç sporculara önem verilmemesi & Genç sporcular & $\mathrm{K} 5-\mathrm{K} 8-\mathrm{K} 4$ \\
\hline & Çocukların sokakta oyun oynanması & Sokak futbolu & K9-K 10 \\
\hline & Sistem düzensizliği & Sistem & K12-K16-K18 \\
\hline
\end{tabular}

Katılımcıların Türkiye'de futbolcu yetişememesi üzerine görüşleri analiz edildiğinde; Tesisleşme yetersizliği”, "Eğitim yetersizliği”, "Genç sporcuların önemsenmemesi”, "Sistem 
düzensizliği", "Çocukların sokakta oyun oynamaması", "Maddi durumların kısıtlılığı" ve "Denetim yetersizliği”" gibi kavramlar üzerinde durdukları görülmüştür (Tablo 2).

Katılımcılar, tesisleşmenin futbolcu yetiştirme konusunda önemli bir etken olduğunu ifade etmişlerdir. Katılımcıların ifadeleri şu şekildedir:

K1: '...tesisleşmenin olmaması bizim için büyük bir sorundur."

K2: 'Tesisleşmemizin yetersiz olduğunu düşünüyorum, sporcularımızın iyi sahalarda ve tesislerde çalı̧̧ması gerekir",

K3: '...Tesisler çoğalmall, Antrenörler iyi eğitilmelidir.",

K4: '...Tesisleşme yeterli değil, sporcu yetiştirmeye önem verilmelidir.',

K6: 'Düzenli tesisleşme içerisinde bulunulmalıdır'"

K11:'Kulüplerin tesisleşmemesidir. Sporcu yetiştiren kulüplerin tesise önem vermesi gerekmektedir. Sporcular belli bir düzen içinde yetişstirilerek, eğitilmelidir."'

K14: 'Tesisleşme anlamında çalışmalar yapılmalıdır. Kampüs şeklinde tesisler kurulmall, okul ve antrenman düzenli bir şekilde devam etmelidir.",

K16:"Tesis eksikliğinin sporcu yetişmesi ve yetişmemesi üzerinde etkisinin olduğunu düşünmekteyiz."

Nacar’a (2011) göre; sporun toplumda önem kazanması ve yayılması bununla birlikte devamlı başarıların elde edilmesinde sahip olunan tesislerin işletilmesi, nitelikleri, nicelikleri yeterlilik ve doğru politikalara da bağlıdır. Spor eğitimi veren kurumlar, spor tesislerinin planlanması ve kapasitelerinin artırılması, şüphesiz ki spor eğitim kalitesini artıracaktır. Spor eğitimi veren kurumlarda, spor tesislerinin varlığı o kurumun performansında önemli bir yer tutar. Ayrıca spor tesisleri bir kurumun toplum karşındaki imajını belirler. Bu ifade katılımcıların görüşleri ile örtüşmektedir. Bu sonuç itibari ile tesisleşmenin kulüpler ve sporcular üzerindeki etkisinin büyük önem taşıdığı ve ülkelerin sporcu yetiştirmek için yaptı̆̆ yeniliklerin tesisleşme ile başladığı sonucuna varılmaktadır.

Katılımcılar sistem düzensizliğinin alt yapıdan futbolcu yetişememesinde önemli bir etki olduğu yönünde görüş bildirmişlerdir. Katılımcıların ifadeleri;

K12: 'Belirli bir sistemimiz olmaması, bir program dâhilinde hareket edilmemesi organizasyonlarımızın daha kaliteli olması gerekmektedir. İşler günlük değil planlı bir şekilde geleceğe yönelik yapılmalıdır." 
K16: 'Planlama ve eğitim programlarının sporcu yetişmesi ve yetişmemesi üzerinde etkisinin olduğunu düşünmekteyiz."

K18:'Planlama ve koordinasyondaki eksikliğimiz bizi Avrupa ve dünyanın gerisinde birakiyor",

Katılımcıların belirttiği görüşlerden bir diğeri genç oyunculara önem verilmemesidir. Katılımcıların görüşleri;

K5: 'Genç sporculara önem verilmemektedir.",

K8: 'Altyap sporcularınin önemsenip bu konuda dikkat edilmelidir."

K4: 'sporcu yetiştirmeye önem verilmemesi...",

Katılımcılara göre eğitim yetersizliği de futbolcu yetişememesi konusunda önem bir etkendir. Katılımcıların ifadeleri;

K1: 'Teknik sorumluların eğitimlerinin yetersiz olmasıdır.,"

K3: 'Antrenörler iyi eğitilmelidir. Ĕgitim kalitesine özen gösterilmelidir.",

K7: '....sportif ve akademik eğitimlerin az olması, Eğitimlerin düzenli olmamasıdır',

K11: 'Sporcular belli bir düzen içinde yetişsirilerek, eğitilmelidir"'

Katılımcılar, çocukların sokakta oyun oynamasının da bir etken olduğu yönünde görüş bildirmişler. Katılımcı görüşleri şu şekildedir;

K9: 'Oyunun sokakta oynanmamasl, semt sahalarinin olmamast, ilgi alanlarinin farklılaşması..."

K10: 'Sokaktan sporun kalkması, spor alanlarının yok olması...",

Bir Katılımcı denetim yetersizliği ve maddi durumların kısıtlılığı ile ilgili görüş bildirmiştir.

K1: 'Denetimlerin yetersiz olmasl ve maddi durumlar sporcu yetişmesinde önemli unsurlardir."

2. Ana Temada kulüp bazında altyapıdan futbolcu yetişmesi için ne tür çalışmalar yapıldığ üzerine görüşlerden elde edilen verilerin analizi ile sağlanmış kodlamalar 'alt temalar' adı altında altı başlıkta toplanmıştır. 
Tablo 3. Kulüp bazında altyapıdan futbolcu yetişmesi için yapılan çalışmalar üzerine bulgular

\begin{tabular}{|c|c|c|c|}
\hline & $\begin{array}{l}\text { Görüşme sonucu ortaya } \\
\text { çkan kodlar }\end{array}$ & Alt temalar & Katılımcilar \\
\hline \multirow{8}{*}{$\begin{array}{l}\text { Kulübünüzde } \\
\text { altyapınızdan futbolcu } \\
\text { yetişmesi için ne tür } \\
\text { çalışmalar } \\
\text { yapıyorsunuz? }\end{array}$} & Yetenekli Futbolcuların & Yetenek Seçimi & K1-K2- K12- K15- \\
\hline & Seçilmesi & & K16- K17 \\
\hline & Futbolcuların Eğitilmesi & Eğitim & K2-K3- K4- K7- K8- \\
\hline & & & K16- K18 \\
\hline & Psikolojik danışman desteği & Psikolojik destek & K3-K4- K6- K9- K16 \\
\hline & Futbol okulları organizasyonu & Futbol okulları & $\begin{array}{l}\text { K4- K5- K11- K16- } \\
\text { K17 }\end{array}$ \\
\hline & $\begin{array}{l}\text { Üniversiteler ve okullar ile } \\
\text { işbirliği }\end{array}$ & $\begin{array}{l}\text { Üniversite ve okul } \\
\text { işbirliği }\end{array}$ & K6 \\
\hline & Aile kulüp işbirliği & Aile ile işbirliği & K3-K16 \\
\hline
\end{tabular}

Katılımcıların kulüplerinde altyapıdan futbolcu yetişmesi için yaptığı çalışmalar incelendiğinde; "Yetenek seçimi”, "Eğitim”, "Psikolojik destek”, "Futbol okulları”, “Üniversite ve okul işbirlikleri”, “Aileler ile işbirliğì" yapılması gibi kavramlar üzerinde durdukları görülmüş̧ür (Tablo 3).

Katılımcıların futbolcu yetiştirmede en çok 'Eğitim' kavramı üzerinde durdukları gözlemlenmiştir.

K2: 'Oyuncularımıza gerektiğinde özel antrenman yaptırırız. Oynadlğı pozisyonlara göre ciddi eğitimler veririz."

K3: 'Sporcularımızı düzenli bir şekilde eğitmekteyiz.',

K4: 'Sporcularımıza teknik ve psikolojik açıdan destek vermekteyiz. Futbol okullarına önem vermekteyiz.",

K7: 'Iyi şartlarda eğitim vermekteyiz.",

K8: "Altyapımızda bu yll yabancı bir antrenör göreve getirdik, onun bilgi ve birikimlerinden faydalaniyoruz.",

K9: 'Sporcularımıza yakından ilgi göstererek iyi eğitim veriyoruz.",

K13: 'Dayanışma ile ahlaki yönden iyi bir eğitim ile düzgün sporcular yetiş̧tiriyoruz."

K14:"'Tüm organizasyonlara düzenli bir şekilde katıllyoruz. Eksiksiz her şeyi yapmaya çallşlyoruz."

K15: 'Yedi yaşından itibaren kurmuş olduğumuz eğitim gruplarımız ile küçük yaşta futbol eğitimi vererek yaş büyüdükçe genç futbolcu adaylarımızın üzerine koyarak gelmelerini sağlamak amaçlanmaktadır.",

K16:'Sporcularımızın zihinsel gelişimleri de bedensel gelişimleri kadar önem taşımaktadır. Bu amaçla eğitim programlarımız onların teknik anlamdaki becerilerini taktik 
zekâları ile birleştirmeyi hedeflemektedir. Sağllklı zihinlerin yetişmesi bizim için öncelikli bir hedeftir.",

K18: 'Bilimden, teknolojiden ve gözlemlerimizden yola çıkarak nitelikli, kaliteli ve üstün kapasitede sporcular yetiştirmeyi amaçlamaktayız."

Katılımcıların üzerinde en çok durduğu görüşlerden biri de yetenek seçiminin önemidir. Katılımcı görüşleri;

K1:'...Futbol okulları kulüp okul futbol projeleri organizasyonlarını düzenleyerek kulübümüz bünyesine futbolcu kazandirmaktayız.",

K2: 'İlçemizdeki ve çevre ilçelerdeki okulları gezerek yetenekli çocukları seçerek altyapımıza kazandirlyoruz.",

K12: 'Ulusal bazda 300' e yakın futbolcu izlendi, raporlanip yönetime rapor sunuldu izlenilen futbolcularin 25 tanesi kulüp bünyesine kazandırlld ....'

K15: 'İl genelinde tüm ilçelerde ki okullar taranarak küçük yaşta yetenekli oyuncuların tespiti yapılıp kulübümüze kazandırllmaktadır.",

K16:'Ülkemizin farklı bölgelerindeki müsabakalar oyuncu izleme departmanımız tarafindan dikkatle takip edilmektedir. Her sezon başında futbolcu seçmeleri düzenlemekteyiz. Düzenlediğimiz futbol okulu organizasyonlarındaki sporcularımızın da gelişimleri tarafimızca takip edilmektedir.",

K17: '...Bölgedeki özellikli futbolcuları altyapımıza kazandırlyoruz.',

Yetenek seçimi, sorumlu kişiler ve kurumların oldukça dikkatli olmalarını gerektiren önemli bir organizasyondur. Genç yeteneklerin gelişimi yalnızca eğitim kurumlarına bağlı olmamakla birlikte düzenlenecek müsabakalar ve oyunlarla kazanılabilmektedir. Spor kulüplerinin bu müsabakaları ve yarışmaları düzenlerken belirli hatalar yaptığı düşünülmektedir. Branşlaşmadaki zaman süreci, aşırı antrenman, yarışma ve rekabet olgusunun daha ön planda olması, bazı genç sporcularla daha çok ilgilenilmesi, psiko-sosyal gelişimin göz ardı edilerek fiziksel gelişime daha çok önem verilmesi, yaş gruplarının uygun çalışmalar yapmaması gibi hataların azaltılması yetenek seçimi sürecinde daha fazla fayda sağlayacağ düşünülmektedir (Küçük, 2009).

Katılımcıların üzerinde durduğunu başka bir konu futbol okullarıdır:

K4: '...Futbol okullarina önem vermekteyiz.",

K5: 'Düzenlediğimiz futbol okullart ile altyapımıza futbolcu kaynağı sağlamaktayız.", 
K11'”... Geniş çapta futbol okulları projemiz var Konya'da ilçelerde ve diğer birkaç ilde futbol okulları açıyoruz, futbol okullarına yatırım yapıyoruz."

K16:" Ülke çapında 105 futbol okuluna sahibiz, yaklaşık olarak 10 bin genç sporcu bu okullarda önceden hazırlanmış antrenman programlarımıza göre futbol eğitimi almaktadır.'”

K17: 'Futbol okulları projelerimizi gerçekleștirmekteyiz.'

Günümüzde spor okulları daha çoğunlukla futbol okullarına dönüşmüş ve hemen hemen tüm kulüplerin faaliyet alanı haline gelmiştir. Spor kulüpleri, futbol akademi ve futbol altyapı organizasyonlarıyla gelecekteki futbolcularımızı tespit etmek ve yetiştirme sürecinde önemli sorumlulukları sahiplenmektedirler. $\mathrm{Bu}$ süreçte yetenekli gençlerin tespiti ve futbola kazandırılması kulüplere de maddi olarak getiri sağlayacaktır (Meral 2010). Bu görüşler doğrultusunda, spor okullarının alt yapıdan futbolcu yetişmesinde önemli bir etken olduğu söylenebilmektedir.

Katılımcılar futbolcu yetiştirmede psikolojik danışman desteği aldıklarını da belirtmişlerdir.

K3:"Sporcularımızı düzenli bir şekilde eğitmekteyiz. Bunun yanı sıra psikolojik danışmanımızdan destek almaktayız.

K4: "Sporcularımıza teknik ve psikolojik açıdan destek vermekteyiz."

K6: 'Psikolojik açıdan da sporcularımıza destek veriyoruz. Erciyes Üniversitesi ile iş birliği içerisinde çalışmaktayız.",

K9: 'Psikolojik danışmanlardan destek alıyoruz...",

K16: 'Genç sporcularımızın psikolojik durumlarını olumlu bir şekilde güçlendirme amacı ile psikoloji performans danışmanlarımız ve antrenörlerimiz doğru yaklaşım metotları ile çalışmaktadır.",

Spor kulüplerinde spordan anlayan spor psikologlarına gereksinim vardır. Bunlar, uzman doktor veya psikolog değil, futbolu bilen, futbolcuların saha içerisindeki psikolojilerinden anlayan spor psikoloğu veya spor danışmanı olmalıdır. Antrenör veya teknik direktörler futbolcuları; fiziksel, kuvvet, sürat, dayanıklılık v.b. çalışmalar ile spor psikologları da psikolojik yönden, zihinsel ve duygusal egzersizlerle hazırlamaktadırlar (Eygü, 2009). Bu görüşler neticesinde, alt yapıdan futbolcu yetiştirmek isteyen futbol kulüplerinde psikolojik danışmanların önemli olduğunu söylemek mümkündür.

İki katılımcı aileler ile işbirliği yaptığını belirtmiştir. 
K13: 'Kulübünün kültürel değerlerini ön planda tutarak kişiye odakll, saygllı aile ve velilerle birlikte işbirliği içerisindeyiz.",

K16: " ...aile okul ilişkileri koordinatörü, beslenme uzmanı, psikolojik performans danışmanı ve sağlık ekibi bulunuyor."

Bayraktar (2016)'a göre, genç futbolcunun gelişim sürecinde futbolcunun kariyerini ve gelişimi ilgilendiren tüm durumlar kulüp görevlileri tarafından hem ailesi ile eğer varsa futbolcu temsilcisi ile de paylaşılmalıdır. Sporcunun, ailesinin temsilcisinin ve kulübün bu süreçte ortak kararlar alıp ve bu kararlar üzerinde mutabık olmasının önemli olduğu düşünülmektedir. Sporcuya dışarıdan yapılan müdahaleler, yanlış yönlendirmeler sporcunun yanlış karar almasına ve kariyerinde belirsizliklere neden olabilmektedir. Antrenör grubu bu süreçte sporcunun gelişimi ve kişisel durumunu takip ederek sporcunun yaşayacağı olası bir performans kaybı ve olumsuz düşüncelerinin önüne geçebilmektedir. Bu bağlamda, genç futbolcuların yetişme sürecinde aileleri ile olan iletişim boyutunun önemli olduğu söylenebilmektedir.

Bir katılımcı üniversite ile işbirliği yapıldığını belirtmiştir.

K6: "Erciyes Üniversitesi ile iş birliği içerisinde çalışmaktayız."

Katılımcı görüşü neticesinde, üniversiteler ile yapılacak işbirliği ile alt yapıdan futbolcu yetiştirilirken bilimsel temellere dayanarak antrenman programlarının hazırlanmasının önemli olduğu söylenebilmektedir. Türkiye Futbol Federasyonun 2015 yılında yaptı̆̆ incelenmiş ve 25 farklı üniversite ile işbirliği yaparak ilkokullarda 6-10 yaş arasındaki çocuklara temel futbol eğitiminin verilmesi amacıyla KKTC'den de üç üniversitenin katıldığı proje kapsamında, Milli Eğitim Bakanlığı'nın da desteği ile üniversitelerin BESYO bölümlerinde ve Spor fakültelerinde "futbol uzmanlık" alanında eğitim gören 3. ve 4. sınıf öğrencileri, ilkokullara giderek 6-10 yaş grubundaki çocuklara temel futbol hareket eğitimi vererek stajyer antrenörlerin 8 ay boyunca vereceği bu eğitimle ilkokul öğrencilerinin süreklilik sağlanan bir yapı içerisinde futbolla buluşmasının hedeflendiği görülmüş̧ür. Bu sonuçlar neticesinde, üniversitelerin önemli bir yardımcı olduğu ve destek alındığı sonucuna ulaşılmaktadır.

3. Ana Tema'da Türkiye'de altyapıdan futbolcu yetişmesi için yapılabilecek çalışmalar nelerdir üzerine görüşlerden elde edilen verilerin analizi ile yapılan kodlamalarda ' alt temalar" yedi başlık altında toplanmıştır. 
Tablo 4. Türkiye'de altyapıdan futbolcu yetişmesi için yapılabilecek çalışmalar

\begin{tabular}{|c|c|c|c|}
\hline & $\begin{array}{l}\text { Görüşme Sonucu Ortaya } \\
\text { Çıkan Kodlar }\end{array}$ & Alt Temalar & Katılımcılar \\
\hline \multirow{5}{*}{$\begin{array}{l}\text { Türkiye'de altyapıdan } \\
\text { futbolcu yetişmesi için } \\
\text { yapılabilecek } \\
\text { çalışmalar nelerdir? }\end{array}$} & $\begin{array}{l}\text { Genç futbolculara şans verilmesi } \\
\text { Maddi imkânlar }\end{array}$ & $\begin{array}{l}\text { Genç futbolcular } \\
\text { Maddi durum }\end{array}$ & $\begin{array}{l}\text { K1- K2- K7- K10- K18 } \\
\text { K1- K4- K5 }\end{array}$ \\
\hline & Antrenör eğitiminin önemi & Antrenör eğitimi & $\begin{array}{l}\text { K2 -K3- K4- K5- K6- } \\
\text { K8- K11- K14- K16 } \\
\text { K17 } \\
\text { K4-K5- K6- K9- K11- } \\
\text { K12- K13- K14- K16- } \\
\text { K18 }\end{array}$ \\
\hline & Okul saatlerinin düzenlenmesi & Okul saatleri & K4- K14 \\
\hline & $\begin{array}{l}\text { Kulüp yönetimlerinin gençlere } \\
\text { bakış açısı }\end{array}$ & Yönetim & K4-K10- K13- K16 \\
\hline & TFF altyapı düzenlemeleri & Federasyon & $\mathrm{K} 1-\mathrm{K} 15$ \\
\hline
\end{tabular}

Tesisleşmenin önemi bu temada ön plana çıkmış olup 10 katılımcı tesis konusunda görüş̧ belirtmiştir.

K4: 'Tesisler yenilenmeli..."

K5: 'Tesisleşmeye destek verilmeli, hem tesisler hem antrenörler denetlenmelidir.",

K9: 'Tesisleşme gerekli, fiziki şartların sağlanması tesis anlamında...'”

K11: 'Tesisleşme gereklidir.',

K12: 'Daha çok futbol sahası daha çok tesis ve bunların denetlenmesi gerekir.',

K14: 'Tesislerimizi geliştirmeliyiz. Büyütmeliyiz. Nizami sahalarda eğitim vermeliyiz.",

K16: 'Üst düzey teknoloji ve yeniliklerin kullanıldlğı tesisler gerekir.',

K18: 'Tesis şartları düzeltilmeli, futbol sahaları çoğaltılmalıdır.',

Katılımcıların görüşlerine göre, antrenör eğitiminin üzerinde en çok durulan görüşlerden birisi olduğu görülmektedir. Katılımcı görüşleri;

K2: "Antrenör seçimleri doğru olmalıdır."

K3: "Antrenörler eğitilmeli ve öğretime yönelik seçimler yapılmalıdır.",

K4: "Antrenör eğitimleri önemsenmelidir.",

K5: 'Eğitimli antrenörler yetişstirilmelidir.",

K6:'Donanıml antrenörler bunların hepsi birer bütündür. Kulüp içi eğitimler sıklaştırılmalıdır."

K8: '’...Hak ederek görev başına gelmiş antrenörler ile çalışılmall, Antrenörler iyi eğitim almalıdır."

K11: 'Antrenörlerin eğitmenlerin kalitesi arttırllmal, iyi eğitilmelidirler.",

K14: 'Eğitim düzeyimizi geliş̧tirerek antrenörlerimizi de eğitmeliyiz.", 
K16:"Altyapılarda daha fazla antrenör çalışmalıdır. Akademileşme için çalışmalar başlamalıdır.",

Erdoğan (2011), yaptığı araştırmada, antrenörlerin eğitiminin kurumsal ve yönetmelikler açısından karmaşık bir yapıda bulunduğunu, tek bir temel yapı yerine birçok temel yapı olduğunu ve birimler arası koordinenin sağlanmamasından dolayı bu karmaşıkların yaşandığını belirtmiştir. Federasyonun düzenlediği antrenörlük eğitimi kurslarında B.E.S.Y.O ve Spor Bilimleri Fakültesi mezunlarının kurslara katılımlarda geri planda kaldığı sonucuna ulaşmıştır. Yapılan çalışmalar ve katılımcı görüşleri neticesinde, antrenörlerin eğitimlerinin kalitesinin artması yönünde çalışmalar yapılması gerektiği sonucuna ulaşılmaktadır.

Genç futbolculara şans verilmesi üzerinde durulan bir diğer görüştür. Katılımc1 görüşleri;

K1: '...Sporculara güvenilip şans verilmesini düşünmekteyim,'

K2: "Genç futbolculara gerekli maç şansı verilmelidir.",

K7:"'Altyapıdaki futbolculara oynama şansı verilmesi, sürekli şans bulmaları ve değerlendirilmeleri..."

K10:"'Altyapı oyuncuları şans bulmalı ve fazla maç oynatılmalı, sabredilerek altyapı oyuncularınin arkasinda durulmalıdır."

K18: 'Profesyonel takımlarda genç oyunculara şans verilmedir"'

Bayraktar (2016)'a göre, genç futbolcunun yetiştiği ortamda teknik adamlar güven ve aidiyet havası oluşturabilmelidir. Aynı zamanda, genç sporcuların tecrübeli ve saygın sporcular ile bir araya gelmesi onlarda daha iyi seviyede aidiyet, özgüven ve saygınlık sağlayacağ 1 düşünülmektedir. $\mathrm{Bu}$ çalışmalar neticesinde, altyapıdaki futbolculara şans verilmesi ile profesyonelleşme sürecinde genç futbolculara önemli katkılar sağlayacağını söylemek mümkündür.

Katılımcıların, yönetim faktörü ile ilgili görüşleri;

K4: "Altyapılar kulüplerinden ayrılmadan, ayrı bir idari kadro ile yönetilmeli yönetim olarak bağımsızlaşmalı fakat kulüp yönetimine hesap vermeli, ",

K10: "yönetimlerin ve profesyonel takım hocalarının altyapıya dönük olması altyapıyı önemsemesi"

K13: 'işin ehli kişiler işin başında olmalıdır."

K16: 'kurumsallaşmışspor kulüpleri altyapıdan sporcu çıkmasını săglayabilir.", 
Türk futbol kulüplerinin yönetim yapısının, modern futbol endüstrisinin gerektirdiği, çok yönlü mekanizmaya henüz ulaşmadığını yapılan araştırmalar ortaya koymaktadır. Kulüp yönetimleri, takımlarını, endüstriyelleşen futbol yapılanması içerisinde yeniçağın gereksinimlere ayak uydurabilecek çalışmalara gereğince yönlendirememektedir (TKYD, 2009). Belirtilen görüşler neticesinde, alt yapıdan futbolcu yetiştirilebilmesinde kulüp yönetimlerinin büyük bir etken olduğu görülmekte olup, özellikle alt yapıdan sorumlu ayrı bir yönetimin olması gerektiği düşünülmektedir.

Üç katılımcı maddi durum üzerine görüş bildirmiştir:

K1: 'Maddi imkânlar yerine getirilerek maddi sıkıntılar giderilmelidir.",

K4: "maddi konular gözden geçirilmeli antrenör eğitimleri önemsenmelidir.",

K5: "Altyapılar mali yönden güçlenmelidir."

İki katılımcı okul saatlerinin düzenlenmesi ile ilgili görüş bildirmiştir.

K4: 'okul saatlerinin spora göre düzenlenmesi..."

K14: 'Eğitim saatlerini düzgün bir şekilde tasarlamallyzz.",

Katılımcılar futbol federasyonun da görevleri olduğu konusunda görüş bildirmişlerdir.

K1: 'TFF'nin zorunluluk koyması gibi çeşitli talimatları olmalıdır.",

K15: 'TFF tarafindan belirlenecek bir oranda altyaptya aktarmalart sağlanmalı ve bu paraların altyapı için kullanılıp kullanılmadığı denetlenmeli",

Eğitim-öğretim, tesisleşme gibi konularda Türkiye Futbol Federasyonu'nun misyonu uluslararası standartları yakalamak, çağdaş hedeflerle, ülke çapında belirli bir spor kültürüne sahip olmak için gerekli çalışmalar yapmak, ekonomik anlamda da büyüyen bir futbol ortamına sahip olmaktır. Vizyonu ise kurumsallaşmış, çağdaş bir futbol yapısı, ülke çapında yaygın katılımın artması ve uluslararası büyük organizasyonlarda yer alabilmektir (Akkoyun, 2014).

\section{SONUÇ ve ÖNERILLER}

Ülkemizdeki en üst düzeydeki lig olan, Spor Toto Süper Lig'de yer alan 18 futbol kulübü incelendiğinde, 2017-2018 sezonunun ilk yarısında altyapılarından yetiştirdiği oyuncuların ligde oynama oranlarının düşük olduğu görülmüş bunun neticesinde de Spor Toto Süper Lig'deki takımların alt yapıdaki sporculara yer vermeme nedenlerinin üst düzeyde performans gösterecek nitelikli futbolcuların olmadığı düşüncesini doğurmuştur. Bu bağlamda, bu çalışmada profesyonel futbol kulüplerindeki alt yapı sorununu değerlendirerek, ülkemizde alt yapıdan futbolcu 
yetiştirilememesinin nedenleri, kulüplerin alt yapıdan sporcu yetiştirebilmek için neler yaptıkları ve altyapıdan futbolcu yetiştirilebilmesi için neler yapılabilir noktasını değerlendirilerek öneriler sunulmuştur.

Araştırma neticesinde, ülkemizde alt yapıdan futbolcu yetişememesinin temel nedeni olarak tesisleşme yetersizliği olduğu görülmektedir. Antrenman yapılacak tesislerin azlığı, var olanların da yeterli düzeyde olmadığı görülmektedir. Ayrıca çocukların sokaklarda futbol oynamamaları ve sokaktan sporu kalkması da bir neden olarak görülmektedir. Dünyadaki bütün iyi futbolculara bakıldığında sokakta futbol oynadıkları haz neticesinde kariyer olarak futbolcu olmayı hedefledikleri görülmektedir. Bu bağlamda, katılımcı görüşlerine göre çocukların sokakta top oynamadıkları buna bağlı olarak da gelecekte alt yapıdan yetişecek futbolcular bulunamayacağı yönündedir. Ayrıca, katılımcıların antrenörler eğitimlerinin alt yapıdan futbolcu yetiştirmede yetersiz olduğu yönünde görüş bildirildiği görülmektedir. Bunula birlikte, katılımcılar, genç futbolculara verilen değer seviyesinin düşük olduğunu, sporcu yetiştirmeye yeterince önem verilmediği söylenmektedirler. Aynı zamanda, altyapı organizasyonları ile ilgili sistemsel düzensizliklerin olduğu, işlerin planlanmadığ ve eğitim programlarının eksikliği olduğu alt yapılardaki işleyişler ile ilgili olarak denetim mekanizmasının yeterli olmadığı ve alt yapıya verilen maddi desteğin yetersiz olduğu ifade edilmektedir.

Katılımcılara, kulüplerinde futbolcu yetiştirme ile ilgili yaptıkları çalışmalar sorulduğunda; genç futbolculara eğitim verdiklerini, gerektiğinde genç futbolcularla özel antrenman yaptıklarını düzenli aralıklarla bölgelerinde yetenek seçimi yaptıklarını, futbolcularını psikolojik anlamda destek sağladıklarını, futbol okulları açtıklarını, aile-kulüp işbirliği ile birlikte üniversite-okul işbirliği içerisinde olduklarını, kulüp-okul-futbol projelerinde yer aldıklarını belirtmişlerdir.

Katılımcılar, ülkemizde alt yapıdan futbolcu yetişebilmesi için öncelikli olarak mevcut tesislerin iyileştirilmesi, tesislerin sayısının arttırılması, aynı zamanda tesislerin büyütülmesi ve teknolojik anlamda tesislerin yenilenmesi gerektiği üzerinde durmuşlardır. Ayrıca katılımcılar, antrenör seçimlerinin doğru yapılması, antrenörlere alt yapıdaki futbolcuların gelişimlerini sağlamaya yönelik eğitimlerin verilmesi gerekliliğini vurgulamışlardır. Bununla birlikte katılımcılar, genç futbolculara as takımda şans verilmesi ve kulüp yöneticilerinin gençlere bakış açılarını değiştirmelerini önermektedirler. Gençlere maddi destek verilmesi, yönetimlerin alt yapıya değer vermesinin sağlanması ve altyapı yönetimlerinin ayrı bir idari yapılanmaya giderek bağımsız bir yönetime sahip olması bir başka katılımcı görüşüdür. Bununla birlikte okul saatlerinin 
Çevik, S., Onağ, Z. (2019). Türkiye'de altyapıdan futbolcu yetişememesinin nedenleri ve çözüm önerileri üzerine nitel bir araştırma. CBÜ Beden Ë̆itimi ve Spor Bilimleri Dergisi, 14 (2), 326-343.

alt yapı antrenmanlarının yapılabileceği şekilde düzenlenmesinin gençlerin hem akademik hem de futbol kariyerlerini bir arada yürütebilmelerine olanak sağlayacağını belirtmişlerdir. Son olarak katılımcılar, Türkiye Futbol Federasyonunun altyapı organizasyon oluşumunu gözden geçirmesi gerektiği ile ilgili önerilerde bulunmuşlardır. Aynı zamanda çocukların sokakta oyun oynamaya teşvik edici projelerin geliştirilmesi, genç futbolcuların maddi ve manevi yönden desteklenmesi ve denetim mekanizmalarının iyileştirilmesi önerilmektedir.

\section{KAYNAKLAR}

Akkoyun, S. (2014). Türkiye'deki futbol kulüplerinin alt yapılarının yapılanması, yönetim biçimleri, idari yapısı ve Avrupa'daki örneklerle kıyaslanması. Yayımlanmamış yüksek lisans tezi, , İstanbul Kültür Üniversitesi, İstanbul

Erdoğan, B. S. (2011). Türkiye'deki antrenör eğitiminin ilkesel ve yapısal problemlerinin incelenmesi, Yayımlanmamıs yüksek lisans tezi, Ankara Üniversitesi, Ankara.

Eygü, H. (2009). Spor psikolojisi ve Türkiye'deki futbol hakemlerinin hakemlik psikolojileri üzerine bir araştırma, Yayımlanmamış yüksek lisans tezi, Atatürk Üniversitesi, Erzurum.

Kurumsal yönetim ilkeleri ışı̆̆ında Türk futbol kulüpleri yönetim rehberi - Türkiye Kurumsal Yönetim Derneği - (2009)

Küçük, V.(2009). Futbolda yetenek seçimi, İstanbul: FGM Yayınları.

Meral, S. (2010). Ailelerin çocuklarını futbol okullarına gönderme sebeplerinin araştırılması, Yayımlanmamış yüksek lisans tezi, Marmara Üniversitesi, İstanbul.

Nacar, E. (2011). Türk spor eğitiminde spor tesislerinin yeterlilik düzeylerinin belirlenmesi, Yayımlanmamış doktora tezi, Fırat Üniversitesi, Elazı ğ).

Strauss, A. \& Corbin, J. (1990). Basics of qualitative research techniques and procedures for developing grounded theory. London: Sage Publications.

Yıldırım, A. ve Şimşek, H. (2006). Sosyal bilimlerde nitel araştırma yöntemleri (6. Basım). Ankara: Seçkin Yayıncılık.

http://tr.beinsports.com/haber/futbol-akademilerde-yetisiyor Erişim Tarihi: 02.05.2017.

http://news.bbc.co.uk/sport1/hi/football/get_involved/4207962.stm, Erişim Tarihi: 02.05.2017.

http://www.11ucgen.com/turk-futbolu-neden-oyuncu-yetistirmiyor/ Emrah Bayraktar Erişim Tarihi: 06.05.2017.

http://www.tff.org/default.aspx?pageID=735, Erişim Tarihi: 06.05.2017.

https://www.ntvspor.net/yazar/emrah-bayraktar/yeni-baslayanlar-icin-futbol-altyapi 5926c1764f10aca5d83d47bf Erişim Tarihi: 06.05.2017. 